\title{
Determinants of FDI in Czech Manufacturing Industries between 2000-2007
}

Eva Michalíková, Elisa Galeotti*

Abstract:

The Czech Republic (and its manufacturing industry) has been a successful recipient of foreign direct investment over recent years. Therefore, it is important to understand the decisions made by foreign investors where to place their investments and how to decide on their location between alternative industries. The aim of this paper is to find and estimate an econometric model describing the determinants of foreign direct investment (FDI) in the manufacturing industry of the Czech Republic between 2000-2007 and to make a review of recent literature on the topic. The econometric model includes several economic variables (for example labor, physical capital, R\&D, profits per labor, Balassa index). Together with simple techniques of estimation (OLS, fixed effects) we used a generalized method of moments (GMM). In an effort to improve the result we used also a least trimmed squares estimator (LTS) from the class of robust estimators as a diagnostic tool for the heterogeneous pattern of data.

Keywords: FDI, manufacturing industry, Czech Republic, GMM

JEL: C01, C23, C51, C82, F21, F40

DOI: $10.2478 / v 10033-010-0012-5$

\section{Introduction}

It is important to understand the decision making process of foreign investors as to where they place investments. Foreign direct investment (FDI) can provide a firm with new markets and marketing channels, cheaper production facilities, access to new technologies, products, skills and financing. For the host country or the domestic firm which receives the investment in the form of $M \& A$, it can provide a source of new technologies, capital, processes, products, organizational technologies and management skills, an increase in employment and competitiveness. Therefore, FDls can give a strong impetus to economic development. On the other hand, the presence of a FDI can bring some hazards: hostile takeovers with the aim of dampening domestic production in that field so that the foreign parent company has less competition, the crowding out of domestic savings by foreign savings, the forced transfer of domestic savings abroad under unfavorable conditions, an increase of wages in sectors with foreign ownership overspill to sectors with domestic firms in which the labor productivity grows at a slower pace, and many others.

The Czech Republic has been an intensive recipient of

* Eva Michalíková

Charles University, Institute of Economic Studies, Prague, Czech Republic and

Faculty of Business and Management, Brno University of Technology, Brno, Czech Republic

E-mail:michalikova@volny.cz

\section{Elisa Galeotti}

Charles University, Institute of Economic Studies, Prague, Czech Republic

E-mail: elisagaleotti@seznam.cz 
foreign capital during the last 15 years. In 1995, FDI in the Czech Republic reached 195,5 billion CZK, in 2000 818,3 billion CZK and in 20051491,6 billion CZK. For years the manufacturing industry was a leading recipient of FDIs even as in recent years the share of manufacturing decreased. In 1995, the share of manufacturing was $64 \%$, while after 2000 the share of inflows of FDI moved to around $38 \%$ and this trend has continued till the present time. Data describing flows of FDI to Czech Republic are summarized in Table 1.

\begin{tabular}{|c|c|c|c|}
\hline Year & $\begin{array}{c}\text { Total FDI } \\
\text { stock } \\
\text { (billions } \\
\text { CZK) }\end{array}$ & $\begin{array}{c}\text { Anual } \\
\text { increase } \\
\text { (billions } \\
\text { CZK) }\end{array}$ & $\begin{array}{c}\text { Share of } \\
\text { manufacturing } \\
\text { (\%) }\end{array}$ \\
\hline 1995 & 195,5 & - & 64 \\
1996 & 234,3 & 39 & 65 \\
1997 & 319,8 & 86 & 55 \\
1998 & 429,2 & 109 & 46 \\
1999 & 631,5 & 202 & 39 \\
2000 & 818,3 & 187 & 38 \\
2001 & 982,3 & 164 & 38 \\
2002 & 1165,5 & 183 & 46 \\
2003 & 1161,8 & $-3,7$ & 42 \\
2004 & 1280,6 & 119 & 40 \\
2005 & 1491,6 & 211 & 38 \\
2006 & 1666,8 & 175 & 36 \\
2007 & 2032,1 & 365 & 37 \\
\hline
\end{tabular}

Table 1: Stock of FDI in Czech Republic and in manufacturing industry, 1995-2007. Source: CNB, own calculation.

Many authors of economic papers and empirical studies are interested in the problem of foreign direct investment and its determinants. Many analyses have considered the problem of the determinants of FDI in the Czech republic and have played an important role in the previous literature (Zamrazilová, 2007; Kadeřábková, 2007; Blonigen, 2005; Benáček, 2000; Benáček and Zemplinerová, 1997; Smarzynska and Spartareanu, 2004; Mody, 2004; Mody, 2007). In the case of determinants, the thrust of the research has focused on why foreign investors prefer some countries over others (crosscountry analysis) or why some sectors dispose of higher flows of foreign capital (cross-industrial analysis) (Benáček, 2000). The second approach has most of its hypotheses in microeconomic theories of production allocation. Many take the classical approach of the application of theories of comparative advantages. However, a substantial part is derived from the new theories of allocation and trade, theories of industry organization and economic geography (Krugman and Obstfeld, 1997 or Dunning, 1980, 1998 and 2000). Moreover, these analyses are based on the theory of specialization (Yang and $\mathrm{Ng}$, 1993).

An econometric model for the analysis of FDI can therefore explain FDI as a function of many factors (Blonigen, 2004; Francis, Zheng, Mukherji, 2009). One of these factors is the size of the market. Such results were presented in studies by Lankes and Venables (1997), Savary (1997), Pye (1998), Walsh (2010) and Altzinger (1999). In other empirical studies, the authors show the important role played by foreign investors in the expected growth of a market (Barrell and Holland 1999) or access to a market (Amiti and Smarzynska Javorcik, 2005).

The size of foreign capital can be influenced also by labor costs (Savary, 1997; Pye, 1998; Holland and Pain, 1998; Bevan and Estrin, 2000; Benáček and Višek, 1999). Additionally, Pye (1998) also specified other important factors: profitability, the political and economic stability of a country or its access to markets. Stability was important also in the study of Lankes and Venables (1997).

The decision of foreign investors also depends on the level of research and development of domestic firms. Benáček and Víšek (1999) presented in their study that foreign investors preferred investment into manufacturing sectors with higher expenditures in research and development. This contradicts Altzinger (1997) who showed in an earlier study that human capital and know-how were not significant factors in investors' decisions. In contrast, Savary (1997) and Pye (1998) described expert knowledge as very important. It is possible that research and development did not play such an important role as it does today.

Another deciding element within the cross-country analysis can be the process of privatization. In the countries of Central and Eastern Europe three different privatization processes were employed. The first (mostly used in the Czech Republic and Slovakia) was based on the principles of coupon books and the sale of state enterprises to domestic residents was preferred. The second (mainly in the Balkan states) sold state firms to their previous managers. The third (almost exclusively in Hungary) sold state enterprises to strategic partners and implemented certain restrictions on foreign agents. Savary (1997) showed that the regions of Central and Eastern Europe were more advantageous for inflows of 
FDI than Southern Europe. On the other hand, Holland and Pain (1998) declared that the method of privatization was the most important factor.

There are a number of other important determinants for the presence of FDI; for example in cross-country empirical analyses an important factor can be distance from the countries of Western Europe (Bevan and Estrin, 2000 or Holland and Pain, 1999). Lankes and Venables did not confirm the importance of this factor. Other influences can be natural resources (Kinoshita and Campos, 2003), total factor productivity (Benáček and Víšek, 1999 or Savary, 1997) or bureaucratic obstructions (Pomery, 1997).

There exist two cross-industry studies describing determinants of FDI in the Czech manufacturing industry: Benáček and Višek (1999) and Benáček and Viššk (1999a). In the first study the authors described the determinants of FDI in the manufacturing sector in 1994, while in the second, they analyzed determinants between 1991 and 1997. The authors concluded that it was not possible to find a universal econometric model describing all the determinants of all sectors in the manufacturing industry. In the Czech economy, there existed two or three groups of industries where the investors behaved differently because their perspectives were different. With the help of robust estimation techniques, they managed to find in both studies that possible determinants of FDI could be, for example, price increases in the industry, total factor productivity, a skilled labor force and/or the profitability of the sectors.

In this paper we will analyze data on 23 sectors of the manufacturing industry between 2000-2007. Our aim is to describe the history of FDI in the Czech Republic and in the Czech manufacturing industry over the last 10 years, analyze important historical events and describe the relevant literature. Finally, we will find and estimate an econometric model describing the determinants of FDI in Czech manufacturing. Our aim is to continue in previous cross-industry empirical analyses and therefore base our study on theories of comparative advantages, theories of allocation and trade, industry organization and theories of specialization and focus in sector analysis.

The paper is organized as follows. Section 2 describes important historical events in Czech manufacturing. Section 3 describes the data and methodology of estimation. Section 4 reports results and section 5 concludes the paper.

\section{Privatization in the Czech Republic and FDI 2000-2007}

The privatization strategy of Czech Repoublic was three-pronged. Restitutions restored assets to those who had owned firms before they were natonalized by the communist regime in 1948. Small-scale privatization consisted primarily of small economic units that were sold at public auctions. The most important program in the Czech Repuoblic was the Large (Mass) privatization which began in 1991 and concluded in 1995 and covered firms not privatized through the first two programs. This privatization allowed for a combination of the following techniques: holding in tenders (typically small businesses), holding in tenders or to a predetermined buyer (medium-sized businesses) - direct sales, and transforming the largest firms into joint stock companies, whose shares were distributed through voucher privatization (almost one half of the total number of all shares), sold for cash or transferred for free to municipalities (Kočenka and Valachy, 2001).

According to the Annual Reports of CNB, the end of 1990s was characterized by extraordinary flows of foreign capital to the Czech Republic. Many large companies were privatized and large foreign trading companies expanded to the Czech Republic. Privatization- especially of financial institutions - and infrastructure contributed substantially to FDI growth.

In 1998, a system of state investment incentives was established and in 2000 a law for investment incentives was ratified. These measures introduced criteria for an award for incentives, for example an income-tax abatement limit for a specific period for newly established or for already existing companies, support for the buildup of infrastructure and/or subsidies for staff training. These incentives were awarded under certain conditions - especially if the investment targeted some preferred sector of the manufacturing industry or underdeveloped regions.

At the beginning of the millennium, the dominant manufacturing sectors were motor vehicles, electric machines, petroleum products, chemicals, and nonmetallic mineral products. In addition, investments in business machines, computers, paper and the food industry have been high. We should mention the year 2005, when more than half of the increase of FDI flows was due to investment in equity, of which the sales of state-owned stakes in Český Telecom and Unipetrol were the largest investment transactions. However, the 
expansion of existing foreign investments also accounted for a considerable share of foreign capital income.

At the end of the period under our consideration (2006 and 2007) there were no major investment projects. With regard to the sector structure of capital invested in the Czech Republic, the situation was the same for the several previous years: the most dominant were services, following by the manufacturing industry. The largest investments in manufacturing were allocated to motor vehicles, petroleum and chemical products.

In the period under consideration, in terms of geographical breakdown the Netherlands, Germany and Austria accounted for the largest share of FDI. Of the CNB statistics recorded between 3000-4000 foreign owned companies, about 70 companies accounted for around half the total FDI.

\section{Data and Methodology of Estimation}

In this paper, we used a panel of 23 sectors from the manufacturing industry (classified according to the Industrial Classification of Economic Activities -- NACE-CZ divisions, the complete list of industries can be found in the Table 2) between 2000--2007. The number of observations is $184(=23 \times 8)$. The time-series aspect of our analysis is very important. Self-reinforcing effects of FDI can be addressed only if there is a time series of FDI. Industries can go through comprehensive reforms during long time periods and a newly made investment could be a follow-up function of past investment. The crosssectional aspect of this study can also be important due to the difficulty of obtaining sufficiently long FDI data (Kinoshita and Campos, 2003).

\begin{tabular}{|l|l|}
\hline & Name of industry \\
\hline 1 & Food products and beverages \\
\hline 2 & Tobacco products \\
\hline 3 & Textiles \\
\hline 4 & Clothes wear, apparel \\
\hline 5 & Tanning and dressing of leather \\
\hline 6 & Wood and products of wood and cork \\
\hline 7 & Pulp, paper and paper products \\
\hline 8 & $\begin{array}{l}\text { Publishing, printing and } \\
\text { reproduction of recorded media }\end{array}$ \\
\hline 9 & Coke, refined petroleum products \\
\hline 10 & Chemicals and chemical products \\
\hline 11 & Rubber and plastic products \\
\hline
\end{tabular}

\begin{tabular}{|l|l|}
\hline & Name of industry \\
\hline 12 & Other non-metallic mineral products \\
\hline 13 & Basic metals \\
\hline 14 & Fabricated metal products \\
\hline 15 & Machinery and equipment n.e.c \\
\hline 17 & $\begin{array}{l}\text { Office machinery and computers } \\
\text { apparatus n.e.c }\end{array}$ \\
\hline 18 & $\begin{array}{l}\text { Radio, television and } \\
\text { communication equipment }\end{array}$ \\
\hline 19 & $\begin{array}{l}\text { Medical, precision and optical } \\
\text { instruments }\end{array}$ \\
\hline 20 & Motor vehicles, trailers and semi-trailers \\
\hline 21 & Other transport equipment \\
\hline 22 & Furniture; manufacturing n.e.c. \\
\hline 23 & Recycling \\
\hline
\end{tabular}

Table 2: List of industries

The data used in this paper come from different sources. The information about foreign capital flows (as a part of information on balance payment) is from the Czech National Bank (CNB). Direct investment according to the CNB includes equity capital, re-invested earnings and other capital covering the borrowing and lending of funds, including debt securities and trade credits, between direct investors and their subsidiaries, associations and branches. Information about the rest of variables is from the Czech Statistical Office (CSO). On this point it is important to stress the fact that data from the CSO each year undergo many methodological changes and revisions. Some data published by the CSO are classified only in NACE-CZ subsections, which are not as detailed as NACE-CZ divisions. Another problem is that some of the data are not accessible to the public. Moreover some data are not available and must be computed with the help of other data. The most substantial problem is the impossibility of obtaining complete data from the 1990's. In comparison with the $\mathrm{CSO}$, information about FDI from the CNB is stable and the numerical data do not change over time.

Our dependent variable is the intensity of FDI. This intensity in the given industry $\$ i \$$ in time $\$ t \$$ is measured by the volume of foreign capital per value added: FDINA for each year and sector (Benáček and Viššk, 1999), avoiding thus the problem of industry size. Normalization of the stock of FDI by the size of value added requires also that the explanatory variables reflect relative intensities, excluding all size effects. 


\subsection{Regression Variables}

Regression variables were chosen on the basis of the main economic theories of location in an open economy. This allocation can be explained primarily by the pure theory of trade. The location of FDI is closely related to comparative advantages of the industries provided the FDI enters a tradable sector of the economy. A foreign investor would not enter into an industry which has no comparative advantage or where returns are low. In our model we commence with a test of factor usage: capital and labor intensities of production, human capital, requirements of natural resources in the industry where FDI can enter. Because FDI entry should also minimize the cost of production, we also include in our analyses indicators for the cost of production - total factor productivity. The changes in relative prices use the Stolper-Samuelson theorem: the changes in relative prices after the opening-up can lead to extensive changes in the allocation of resources and investments (Benáček and Víšek, 1999). We will also include a variable describing profitability or wages. The following explanatory variables will be used in our tests:

\section{Physical Capital and Labor}

The first explanatory variable deals with the Heckscher-Ohlin explanation of investment due to comparative advantages given by the country's relative endowments and factor requirements in production. In this paper we will use the combination of the physical capital per unit of net production KNA and of the labor per unit of net production (LNA). This variable used in our study is denoted $K / L$ (for each year and sector). Since there has been a general assumption that the presence of relatively skilled labor in post-Communist countries is a comparative advantage that attracts FDI, we expect a positive sign for LNA: the higher the labor intensity of production is, the more competitive the production in international markets and the more attractive the industry for FDI. Physical capital per unit of net production, as an alternative for labor intensity, is a scarce and too expensive factor and we expect it to be a statistically significant variable with a negative sign (on the condition that there is no multicollinearity. Although multicollinearity does not bias the coefficients, it does make them more unstable and standard errors may be larger (Wooldridge, 2003). We checked for multicolinearity using a correlation matrix and using a variance inflation factor (VIF, see O'Brien, 2007). The results suggest that there are no problems with collinearity in our regressions). With the combination of these two factors, we expect a negative sign for the estimated parameter of $K / L$, provided the assumption that the post-Communist economies in Central Europe have comparative advantage in labor is valid. $K$ was measured in billions CZK.

\section{Total Factor Productivity (TFP)}

This variable is used as a proxy for the technical efficiency of factor usage: the higher TFP is, the lower the volume of factors necessary to produce a unit value of output (Benáček and Víšek, 2000). This means that we expect a positive sign for this variable. There are a number of ways how to estimate TFP. By considering an aggregate Cobb-Douglas production function we get

$$
T F P_{i t}=V A_{i t} / K_{i t}{ }^{a} L_{i t}^{b}
$$

where $a$ denotes the capital's share of the value added and $b$ denotes the labor share of the value added. We suppose that $a+b=1$. It is often assumed that the reasonable estimate for $a$ is between 0,25 (Prescott, 1998) and 0,35 (Collins, Bosworth and Rodrik, 1996) or $a$ is set to 0,3 (Caselli, 2005 or Hall and Jones, 2003). We will take the labor's share in the value added in industry as a proxy parameter $b$.

\section{Change of Nominal Producer Prices over Time (PPI)}

This inflationary indicator measures price changes by the producers for their output. The higher this index, the higher the potential for the growth of the industry and investments in this industry. The autonomous industrial price "hikes" can be explained by growing market power (e.g. due to the FDI entry) or the increase in the quality (or the image) of products or simply by a faster world-wide boost in demand for products in the given industry. Thus, a positive sign is expected. The Stolper-Samuelson theorems for location of trade and growth are consistent with this hypothesis.

Labor Cost in the Host Country Relative to the Investor Country (RULC)

Firms will be attracted to industries where labor cost in their sector of activity are low relative to producing elsewhere. A rise in the index indicates deterioration in competitivensess. Therefore, we expect a negative impact on FDI. Relative unit labor cost is computed as the ratio: 


$$
R U L C_{i t}=U L C_{i t}^{*} / U L C_{i t}
$$

where $U L C^{*}$ it denotes unit labour cost in an appropriately selected partner's country or countries in industry $i$ and year $t$ and $U L C_{i t}$ denotes unit labor cost in industry $\mathrm{i}$ and year $\mathrm{t}$ in the Czech Republic. As parnter countries we také EU15. Unit labor cost is defined as labor cost devided by labor productivity (Havlik, 2005).

\section{Research and Development $(R \& D)$}

The quality of the labor or quality of the production and products can also be an important factor for potential foreign investors. CSO offers different sources of information about R\&D: the number of people employed in R\&D, the number of research workers or the total amount of expenditures on research and development. We decided to use the number of people employed in $R \& D$. The role of $R \& D$ has become more important in recent years, and high expenditures in $R \& D$ or a high number of workers employed in R\&D can also be a sign of high quality. We expect a positive sign for this factor.

\section{Profits per Labor}

This variable was included as a proxy for general competitiveness. FDI should be attracted by more profitable firms or the presence of FDI can spill over to higher profits. Thus, a positive sign of this variable is expected. This variable was measured as profits per number of employees. Profits were measured in billions CZK.

\section{Energy Intensity}

Energy intensity was included as a proxy for natural resources. We have information about different energy requirements: coal, gas, oil, electricity and petrol. In the last ten years, the worldwide prices of these sources of energy have risen. The prices of energy have grown, especially at the end of the period under consideration. Nevertheless, for example in 2001, the prices of electricity for industry in the Czech Republic were among the lowest in the EU and this trend continued until 2004. The prices in 2005 were not nearly as high as those in some countries in Europe. After 2005, the situation had changed. We suppose that the Czech Republic still has a comparative advantage in natural resources. Thus, we expect a significant parameter of this factor with a positive sign. The variable was measured as energy consumption in gigajoules (GJ) and normalized by value added.

\section{Wages}

A higher profitability in industries with higher FDI could spill over to higher wages, especially if there is an inelastic labor supply because of low mobility due to a shortage of flats (Benáček and Víšek, 1999). We expect a significant parameter of this factor with a positive sign. This variable was measured as gross monthly wage in thousands CZK.

\section{Balassa Index of Inter-Industrial Specialization (BAL)}

A tendency to relate FDI with higher export specialization to industries is well observed, even though some high export FDI firms can also be important (Altzinger, 1998). Thus we will test a hypothesis on what kind of revealed comparative advantage is associated with FDI. We expect a positive relationship between FDI and BAL.

The Balassa index is computed as the following ratio:

$$
B A L_{i t}=\frac{X_{i t}-M_{i t}}{X_{i t}+M_{i t}}
$$

where $X_{i t}$ denotes Czech export in industry $i$ and year $t$ and $M_{i t}$ denotes Czech import in industry $i$ and year $t$.

\subsection{Methodology of Estimation}

Among the different possibilities of how to organize and estimate an econometric model we decided to choose the approach of Kinoshita and Campos (2003) or Cheng and Kwan (2000) and to relate current values of FDI to past values of FDI along with other explanatory variables. According to previous studies, the role of past FDI values is formulated as the process of the partial stock adjustment and the time it takes for FDI to adjust to an equilibrium or desired level:

$$
\begin{aligned}
& Y_{i t}-Y_{i t-1}=\alpha\left(Y_{i t}{ }^{*}-Y_{i t-1}\right) \\
& Y_{i t}=(1-\alpha) Y_{i t-1}+\alpha Y_{i t}{ }^{*}
\end{aligned}
$$

where $Y_{i t}{ }^{*}$ is an equilibrium level of the FDI stock and $\alpha$ is less than 1 for stability. The equilibrium level of the FDI stock is determined by $X_{i t}$, a vector of $k \in\{1 \ldots K\}$ explanatory variables described upwards in the previous subsections:

$$
Y_{i t}^{*}=\beta X_{i t}+v_{i t}
$$


where $v_{i t}$ is an error term including the individual (industry) specific effect and the time specific effect. By reformulating the econometric model (1) we will get:

$$
\begin{aligned}
& Y_{i t}=\delta Y_{i t-1}+\lambda X_{i t}++\varepsilon_{i} i t \\
& \varepsilon_{i}=\mu_{i t}+\eta_{t}+u_{i t}
\end{aligned}
$$

where $\delta=1-\alpha$ and $\lambda=\alpha \beta$ are coefficients to be estimated ( $\beta$ is a vector of dimension $1 x K) ; \varepsilon_{i t}=\alpha v_{i t}, \mu_{i}$ is an individual (industry) specific effect and $\eta_{t}$ is a time specific effect. We will analyze model (2) using simple ordinary least squares and fixed effects.

There is one serious problem with estimation of model (2) by simple techniques. The lagged variable $Y_{i t-1}$ and error term $\varepsilon_{i t}$ might be correlated and estimates of such a model could be then inconsistent. Therefore, we should estimate the model with first differences:

$$
\Delta Y_{i t}=\delta \Delta Y_{i t-1}+\lambda \Delta X_{i t}+\Delta \varepsilon_{i t}
$$

Since $\Delta Y_{i t-1}$ and $\Delta \varepsilon_{\text {it }}$ might be still correlated we will use the generalized method of moments (GMM). This method is a general estimation principle, where estimators are derived from moment conditions. Arellano and Bond (1991) proposed the GMM (sometimes called difference, DIFF-GMM) estimator that treats the model as a system of equations, one for each time period. The equations differ only in their instrument/moment condition sets. The predetermined and endogenous variables in the first differences are instrumented with suitable lags of their own levels. Arellano and Bover (1995) or Blundell and Bond (1998) proposed the System GMM (SYS-GMM) estimator to give considerable improvements over DIFF-GMM in small samples. SYSGMM is based on a system compound of first-differences instrumented on lagged levels, and of levels instrumented on lagged first-differences. Since we have a small sample we decided to use a third step of the estimation system GMM estimator. All GMM estimations are carried out using command "xtabond2" for Stata. The validity of instruments is checked by the Sargan test and the second-order correlation of the error term in the firstdifferenced equation is checked by Arellano-Bond statistics, which are asymptotically distributed as $N(0,1)$ (Kinoshita and Campos, 2003). An additional empirical check for small-sample bias is to compare the estimated panel GMM with the corresponding estimates from OLS and simple fixed-effects regression.
However, we must take into account the possibility that our data set is a mixture of industries with heterogeneous behavior among investors (Benáček and Víšek, 1999). This means that it would not be possible to estimate our data by using a simple OLS estimator (which includes all observations in one model). For example, Benáček and Višek (1999b) analyzed 92 industries of the Czech economy and realized that this population appeared to consist of two segments. The first segment contained industries in which the majority of firms behaved as if in a functioning market economy while the second segment contained industries where firms behaved as if still under socialist paternalism.

Thus, we will use one of the robust techniques of estimation to solve the problem of heterogeneous patterns in data sets. Among the available possibilities we will use a simple Least Trimmed Square estimator (LTS). We can describe an algorithm of this estimator as follows. We consider the standard linear regression model

$$
Y_{i}=\beta X_{i}+\varepsilon_{i}
$$

For an arbitrary $b \in R^{p}$ we shall denote by $r_{i}(b)=Y_{i}-b X_{i}$ the $i$-th residual at $b$. Further, we shall use $r_{i}^{2}(b)$ for the $i$-th order statistics among the squared residuals. Finally, let us define the LTS estimator by the extremal problem

$$
b^{L T S}=\arg \min \sum_{i=1}^{h} r_{i}^{2}(b)
$$

where $n / 2 \leq h \leq n$ and the minimization is performed over all $b \in R^{k}$ (Rousseeuw and Leroy, 1987, Vîv\{s\}ek, 1996 and Višek, 2000). In other words, in this extremal problem we are looking for such an argument $b \in R^{p}$ for which sum of $h$ smallest squared residuals is minimal. Finally, we built an OLS estimator for these $h$ observations. Unfortunately, we are limited by the dynamic form of model (2). Because of the presence of a lagged value of response variable on the right side of the equation it is not so easy to exclude some observations out of the data set. Instead of this, we decided to exclude a whole industry or industries. Therefore, we will use this technique only as a diagnostic tool to ascertain if the LTS estimator would systematically exclude (almost) a whole industry or industries in (almost) all the years. 


\begin{tabular}{|c|c|c|c|}
\hline & OLS (a) & FE (b) & GMM (c) \\
\hline Lagged FDI/VA & $0,4577^{* * *}(0,0744)$ & $0,196^{* *}(0,078)$ & $-0,324^{* * *}(0,099)$ \\
Capital per labor K/L & $-0,104^{* * *}(0,032)$ & $-0,372^{* * *}(0,132)$ & $0,673^{* * *}(0,038)$ \\
Profits per labor & $0,395^{* * *}(0,110)$ & $0,181^{* *}(0,151)$ & $8,602^{* * *}(3,261)$ \\
R\&D & $4,682^{*}(2,717)$ & $25,671^{* * *}(5,738)$ & $0,107^{* * *}(0,037)$ \\
Energy intensity & $0,111^{* * *}(0,032)$ & $0,142^{* * *}(0,036)$ & $0,084^{* * *}(0,024)$ \\
Wage & $0,051^{* * *}(0,014)$ & $-0,006(0,040)$ & $0,003(0,006)$ \\
PPI & $-0,008^{*}(0,0044)$ & $0,015^{* * *}(0,004)$ & $-0,176(0,361)$ \\
TFP & $-0,111(0,107)$ & $-0,038(0,140)$ & $-0,319(0,214)$ \\
RULC & $-0,318^{* * *}(0,102)$ & $-0,791^{* * *}(0,128)$ & $0,007(0,143)$ \\
BAL & $0,076(0,131)$ & $0,411(0,397)-0,791^{* * *}(0,128)$ & 184 \\
\hline Number of obs. & 184 & 184 & - \\
\hline Adjusted R & 0,86 & - & - \\
\hline Within R & - & 0,62 & 0,270 \\
\hline Sargan test (p-value) & - & - & 0,007 \\
AB 1 (p-value) & - & - & 0,475 \\
\hline
\end{tabular}

Notes: ${ }^{*}$ significant at $10 \% ;{ }^{* *}$ significant at $5 \% ;{ }^{* * *}$ significant at $1 \%$. Robust standard errors in brackets. Time dummies are included in regressions. Hausmann test rejects the random effects model. Response variable: FDI/VA.

Table 3

\section{Results}

In the first step, we report OLS estimation and fixedeffects panel estimates (Blanchard, Gaigné, Mathieu, 2008). However, both pooled OLS and fixed effects of an autoregressive panel model are subject to biases in the estimation of all model parameters. Thus, we also report the results of the GMM system. Finally, in addition to the results of the GMM estimator we will also cement the results of OLS and fixed effects in an effort to compare the results in terms of an economic interpretation. In all regressions the response variable is FDINA. Table 3 reports the panel regressions: We report pooled OLS and fixed effects models in column (a) and (b) and the GMM model in column (c). All regressions include time dummies to control for time variation due to changes in the economic environment common across industries.

The coefficient of determination for model (a) and (b) is satisfactorily high ( $86 \%$ and $62 \%$, respectively). We present three specification tests for GMM. The Sargan test does not reject the null hypothesis that the overidentifying restrictions are valid. The Arellano-Bond test for $A R(2)$ determined that there is no second order serial correlation. It implies that the model is correctly specified. The coefficient of the lagged FDINA, , is 0.45 in regression (a), 0.19 in regression (b) and 0.32 in regression (c). This means that the coefficient of partial adjustment $\alpha$ is thus 0.55 in the case of model (a) and the net investment in one year is $55 \%$ of the difference between $Y^{*}$ and $Y$. If the steady-state level of the FDINA stock does not change it will take about 2 years for the gap between the equilibrium and the current value of FDINA to close.
We can make an analogous conclusion in the case of models (b) and (c) (Kinoshita and Campos, 2003).

The results of all three indicate that physical capital and labor play an important role in the decision of foreign investors where to place an investment. It seems that in recent years investors have preferred a cheaper alternative - investments into labor intensive sectors while investors shunned capital intensive industries. This result agrees with findings of other studies (Benáček and Víšek, 1999 or Savary, 1997) and also is consistent with our expectations.

The variable describing profits in sectors is significant in all regressions with positive signs. According to our hypothesis, profits in industries attracting FDI should be greater than profits in industries with indigenous enterprises. The results of our tests are consistent with these expectations. In regressions (b) and (c), foreign investors emphasized research and development. The results correspond to our expectations: higher expenditures on $R \& D$ means higher investments from the side of foreign investors, with higher foreign investments spilling over to higher expenditures on R\&D. This variable is significant only on the level of $10 \%$ in regression (a). Although this result is not very strong and conclusive, generally we can believe that $R \& D$ is important for investors.

The variable describing energy requirements is significant, with a positive sign for the estimated parameter. The prices of energy have risen in recent years, but these changes concerned countries throughout the world. The Czech Republic was characterized by lower prices of energy at the beginning of the period under 


\begin{tabular}{|c|c|c|c|}
\hline & OLS (d) & FE (e) & GMM (f) \\
\hline Lagged FDI/VA & $0,633^{* * *}(0,074)$ & $0,173^{* *}(0,074)$ & $0,410^{* * *}(0,077)$ \\
Capital per labor & $-0.123^{* * *}(0,032)$ & $-0,338(0,226)$ & $-0,115^{* * *}(0,034)$ \\
Profit per labor & $2,047^{* * *}(0,371)$ & $0,776^{* *}(0,341)$ & $1,236^{*}(0,728)$ \\
R\&D & $5,669^{*}(2,670)$ & $15,399^{* * *}(5,620)$ & $7,830^{* * *}(2,850)$ \\
Energy intensity & $0,084^{* * *}(0,032)$ & $0,116^{* * *}(0,035)$ & $0,112^{* * *}(0,032)$ \\
Wage & $0,049^{* * *}(0,015)$ & $-0,033(0,041)$ & $0,078^{* * *}(0,021)$ \\
PPI & $-0,011^{*}(0,007)$ & $0,017^{* * *}(0,004)$ & $-0,003(0,005)$ \\
TFP & $-0,058(0,104)$ & $0,012(0,131)$ & $0,139^{*}(0,298)$ \\
BAL & $0,105(0,127)$ & $0,353(0,376)$ & $0,728^{* *}(0,357)$ \\
RULC & $-0,608^{* * *}(0,129)$ & $1,332^{* * *}(0,158)$ & $0,760^{* * *}(0,126)$ \\
\hline Number of obs. & 176 & 176 & 176 \\
\hline Adjusted R & 0,88 & - & - \\
\hline Within R & - & 0,69 & - \\
\hline Sargan test (p-value) & - & - & 0,060 \\
AB 1 (p-value) & - & - & 0,000 \\
AB 2 (p-value) & - & - & 0,108 \\
\hline
\end{tabular}

Table 4: Industry 2 tobacco is excluded. Notes: * significant at 10\%; ** significant at $5 \% ;{ }^{* * *}$ significant at $1 \%$. Robust standard errors in brackets. Time dummies are included in regressions. Hausmann test rejects the random effects model. Response variable: FDI/VA.

consideration compared to European countries and thus continued the tradition of investments in energyintensive industries. On that account, we conclude that the Czech Republic has a comparative advantage in energy requirements.

Relative unit labor cost is highly significant in all three regressions. It means that increases in relative production costs in the Czech manufacturing industry compared to EU15 countries are expected to have a negative effect on investments into these industries.

The variable describing gross monthly wage is significant for models (a) and (c). These results also conform to our expectations. The variable describing the efficiency of factor usage, total factor productivity, is not significant in any model. Surprisingly, the variable PPI, describing inflation rate, is significant only in regression (b). Our data and these results can be misrepresented by a heterogeneous pattern of foreign investors in some industries. We will try to eliminate this influence by using LTS.

As mentioned above, there exists a certain possibility that our data comes from two or more different sectors where investors behave differently. Moreover, some variables are not significant and the results of the fixed effects regression are not very good. Thus, we tried to apply a least trimmed square estimator to our data and monitored these industries which were deleted by most of the observations of the algorithm. Pursuant to the results, the question becomes whether to drop subsequently tobacco (industry 2) or motor vehicles, trailers and semi-trailers (industry 20). Afterwards we estimated these reduced data sets by using pooled OLS, a fixed effects panel estimator and system GMM. The results of these estimates are in Tables 4 and 5. In terms of economic explanation, the manufacture of tobacco products is specific: there have been no workers employed in research and development, while on the other hand the ratio $K / L$ and profits per labor are very high compared to other industries. The sector of motor vehicles, trailers and semi-trailers has a specific position in the Czech Republic and has cardinal importance for the whole Czech economy. The flows of FDI in this industry are extremely high as this sector emphasized research and development, and its profits are higher than those of other industries.

After excluding industry 2 (tobacco) the results of regression (d) and (f) improve only in some details. The coefficient of determination for the model (d) remains high (88\%), and the coefficient of determination increases (69\%). This means that the models fit the data well. As well as in a previous analysis according to the ArellanoBond test, a second order correlation does not detect problems and the Sargan test rejects the null hypothesis. This means that the validity of instruments is correct. Overall, a comparison between OLS and GMM results shows a bias that in most variables is not as great as seen in similar sizes of coefficients in both specifications.

Variable $K / L$ has a negative sign and is significant in models (d), (e) and (f). This result supports our previous findings, that investors probably avoid involvement in industries the expansion of which would require a large financial investment in their capital revamping, the alternative being to start expansion in labor intensive and profitable industries, because the variable profits per labor is also significant and positive (in all three models). Significance of $R \& D$ in all regression reamins unchanging. The level of significance in OLS regression is only $10 \%$. Nevertheless, low p-values in regressions (e) and (f) support our hypothesis that foreign investors emphasize research and development. Variable RULC, which describes competitiveness, is significant in all three regressions with a negative sign. This implies that investors tend toward industries with low labor costs related to productivity. 


\begin{tabular}{|c|l|l|l|}
\hline & OLS (g) & FE (h) & GMM (i) \\
\hline Lagged FDI/VA & $0,5582^{* * *}(0,074$ & $0,220^{* * *}(0,079)$ & $0,273^{* *}(0,123)$ \\
Capital per labor & $-0,111^{* * *}(0,031)$ & $-0,393^{* * *}(0.131)$ & $-0,120^{* *}(0,059)$ \\
Profit per labor & $0,401^{* * *}(0,001)$ & $0,125(0,194)$ & $0,698^{* * *}(0,167)$ \\
R\&D & $6,594^{* * *}(2,685)$ & $27,350^{* * *}(5,869)$ & $7,209^{* *}(3,541)$ \\
Energy intensity & $0,119^{* * *}(0,031)$ & $0,141^{* * *}(0,036)$ & $0,081^{* *}(0,40)$ \\
Wages & $0,046^{* * *}(0,001)$ & $0,080^{*}(0,040)$ & $0,091^{* * *}(0,029)$ \\
PPI & $0,008^{*}(0,004)$ & $0,017^{* * *}(0,005)$ & $0,010(0,009)$ \\
TFP & $-0,105(0,105)$ & $0,001(0,138)$ & $-0,184(0,160)$ \\
BAL & $-0,016(0,134)$ & $0,522^{*}(0,291)$ & $0,315^{* * *}(0,132)$ \\
RULC & $-0,375^{* * *}(0,101)$ & $-0,791^{* * *}(0,128)$ & $-0,362^{*}(0,201)$ \\
\hline Number of obs. & 176 & 176 & 176 \\
\hline Adjusted R & 0,86 & - & - \\
\hline Within R & - & 0,64 & - \\
\hline Sargan test (p-value) & - & - & 0,308 \\
\hline AB 1 (p-value) & - & - & 0,078 \\
\hline AB 2 (p-value) & - & - & 0,716 \\
\hline
\end{tabular}

Table 5: Industry 20 motor vehicles, trailers and semi-trailers is excluded. Notes: ${ }^{*}$ significant at $10 \%{ }^{* *}$ significant at $5 \%$; $^{* * *}$ significant at $1 \%$.Robust standard errors in brackets. Time dummies are included in regressions. Hausmann test rejects the random effects model. Response variable: FDI/VA.
The variable describing the efficiency of factor usage (TFP) is significant on the level of $10 \%$ in regression (f) and this variable has a positive sign. These findings are consistent with our expectations: the higher the TFP, the lower the volume of factors necessary to produce a unitvalue of output, making the industry more attractive for foreign investment. However, this low significance does not bring strong conclusions.

The variable describing inflation (PPI) is significant only for regressions (a) and (b). However, the estimated parameter in regression (a) has a negative sign. According to our expectation, the sign should be positive. By a clear look at the data, we can see that this price index is decreasing for several industries, especially those where FDI flows were high during recent years. In industries with higher FDI, the prices can be pressed down and the negative sign can be the effect of the presence of FDI. There is also a statistical explanation of this problem. In general, if the sign of estimated parameters does not correspond to our expectation, this variable could compensate the non-linearity of some other (usually nonsignificant) variable. This means that the "bad" sign of a parameter does not need to be a problem and that we should not rely only on signs of estimated parameters. On the other hand, the level of significance is only $10 \%$. In any case, we will monitor carefully the results of estimating this parameter in the following regression (without industry 20).

The Balassa index is positive and significant in model (f). A tendency to invest in industries with higher export / import orientation is consistent with this result.The rest of the variables are unchangeable. We can conclude that excluding industry 2 (tobacco) from our data set does not bring substantial improvement.

We will now briefly comment on the results of the last estimated model, where industry 20 (vehicles, trailers and semitrailers) is excluded. The results are summarized in table 5 .

The coefficients of determination of model (g) and (h) are $86 \%$ and $64 \%$. Two specification tests of the GMM show a satisfactory result. With the Sargan test we do not reject the null hypothesis that the instruments are well specified and the Arellano-Bond test does not detect second-order serial correlation. In other words, the model is correctly specified.

Let us control the most problematic variables - PPI, TFP and Balassa index. PPI variables in regressions $(\mathrm{g})$ and (h) are significant on the level of $10 \%$ and $1 \%$, respectively, TFP is not significant in any model. Moreover, PPI is significant with a positive sign in regression (b). This means that the higher this index, the higher the potential for the growth of the industry and investments in this industry. On the other hand results from regressions (a) and (c) do not bring a similar conclusion. Thus we suppose that this factor is not important for investors. The Balassa index suggests that foreign investors are focused on industries which are export or import oriented. This conclusion supports estimates in regressions (h) and (i). The remaining variables are significant, mostly at a level of $1 \%$.

\section{Conclusion}

This paper analyzes some aspects of the behavior of foreign investors in the Czech manufacturing industry to learn about the mechanism of allocation of FDI as a descriptive analysis of the decision-making process of investors who discriminate between manufacturing sectors in one single country. Therefore, we focused on sectoral analysis and estimated panel data of 23 sectors of the manufacturing industry over 8 years (2000-2007) by using different techniques of estimation: OLS, fixed effects and primarily by using a GMM estimator. Together with the GMM estimator, we provided several statistical 
tests controlling the validity of used instruments. One of the most important weakness of this paper, the relatively short time series, is eliminated by certain sensitivity analysis - we estimated nine different regressions, all with the same regressors. The results obtained by simple techniques of estimation mostly correspond to those obtained by GMM.

One of the most important results is the suggestion that the abundance of labor with technical skills is still a comparative advantage in the Czech Republic, while physical capital is relatively more scarce and thus a more expensive factor. Foreign investors prefer industries with a higher quality of labor and flows of foreign capital are closely associated with the number of workers employed in research and development. We conclude that a higher number of these employees effects higher flows of FDI. Foreign capital is also positively associated with energy usage, as foreign investors tend to invest into industries with higher energy requirements. In addition, our hypothesis about profits in these industries was also confirmed in all regression models: industries with higher profits per labor have higher flows of FDI. We suppose that higher profit is the effect of the presence of FDI in industry, which has a circular effect of attracting further investments. Relative unit labor cost is also an important determinant of FDI in Czech manufacturing.

Although there could be more possibilities to exclude industries from our data set (we could take into account also industry - 13 - basic metals or industry 18 - radio, television and communication, because after excluding one of these industries the results do not change and are very similar to the previous two following regression models), in our analyses we tried to drop 2 different industries out of the model: tobacco (no workers employed in research and development, on the other hand the ratio $K / L$ and profits per labor are very high compared to other industries) and transport equipment (where flows of FDI were extremely high). This exclusion does not bring fundamental improvement to the results - only the PPI index or Balassa index became more significant. However, the parameter TFP remains insignificant.

In conclusion, it is very important to note that at the present time the conditions of the Czech economy are changing. These changes will probably also cause changes in the structure of industries and the drain of foreign capital. [

\section{References}

Altzinger W. 1999.Austria's Foreign Direct Investment in Central and Eastern Europe: Supply Based or Market Driven. Paper on 47th conference International Atlantic Economic Conference, Viennas.

Amiti M.,Smarzynska Javorcik B. 2005. Trade Costs and Location of Foreign Firms in China. CEPR Discussion Papers 4978, C.E.P.R. Discussion Papers.

Arellano M., Bond S. 1991. Some Tests of Specification for Panel Data: Monte Carlo Evidence and an Application to Employment Equations. Review of Economic Studies 58, 277-297.

Arellano M., Bover O. 1995. Another Look at the Instrumental Variable Estimation of Error-Components Models. Journal of Econometrics 68, 29-51.

Barrell R., Holland D. 1999. Foreign Direct Investment in Central European Manufacturing: Consequences for Enterprise Restructuring and Labor Productivit. Research of NIESR, London.

Benáček V. 2000. Př́mé zahraniční investice v České Republice: praxe, teorie a aplikace. Politická ekonomie 1, 7-24.

Benáček V., Višek J.Á. 1999. The Determinants of FDI Flows into Czech Manufacturing Industries: Theoretical Background and Empirical Testing. Research of Charles University, IES and ACE Brusel.

Benáček V., Viššk J.Á. 1999a. The Determinants of FDI in the Czech Economy: The Robust Analysis Applied on Industrial Data of 1991-1997. Charles University, mimeo.

Benáček V., Višek J.Á. 1999b. Supply-Side Characteristics and the Industrial Structure of Czech Foreign Trade. Research of Charles Universtity, IES and ACE Brusel.

Benáček V., Zemplinerová A. 1997. Foreign Direct Investment in the Czech Manufacturing Sector. Prague Economic Papers 6 (2), 141-155.

Bevan A., Estrin S. 2000. The Determinants of Foreign Direct Investment in Transition Economies. CEPR discussion paper No. 2638, London, Center for Economic Policy Research.

Blanchard, P.; Gaigné, C.; Mathieu, C. 2008.Foreign Direct Investment. The Lessons from Panel Data. Advanced Studies in Theoretical and Applied Econometrics 46 (3), 663-696

Blonigen B.A. 2006.. A Review of the Empirical Literature on FDI Determinants. Atlantic Economic Journal 33 (4), 383-403.

Blundell R., Bond S. 1998. Initial Conditions and Moment Restrictions in Dynamic Panel Data Models. Journal of Econometrics 87, 115-143.

Caselli F. 2005. Accounting for Cross-Country Income Differences. Handbook of economic growth, Elsevier, 679-742.

Cheng L., Kwan Y. 2000. What are the Determinants of the Location of Foreign Direct Investment? The Chinese Experience. Journal of International Economics 51, 379-400.

Collins S.M., Bosworth B.P., Rodrik D. 2000. Economic Growth in East Asia: Accumulation versus Assimilation. Brooking papers of economic activity, 1996 (2), 135-203.

ČNB - Česká Národní Banka. Foreign Direct Investment. Annual reports, 2000-2006.

Dunning J.H. 1980. Toward an Eclectic Theory of International Production: Some Empirical Tests. Journal of International Business Studies 11 (1), 9--31.

Dunning J.H. 1998. Location and the Multinational Enterprise: A Neglected Factor?. Journal of International Business Studies 29 (1), 4566.

Dunning J.H. 2000. The Eclectic Paradigm as an Envelope for Economic and Business Theories of MNE Activity. Journal of International Business Studies 9, 163-190.

Francis, J.; Zheng, C. Mukherji, A. 2009. An Institutional Perspective on Foreign Direct Investment. A Multi-level Framework. Management International Review, 49 (5), 565-583

Havlik P. 2005. Unit labor costs in the new EU member states. The Vienna Institute for International Economic Studies, Austria

Holland D., Pain N. 1998. The Diffusion of Innovations in Central and Eastern Europe: A Study of the Determinants and Impact of Foreign Direct Investment. NIESR Discussion Paper 137. 
Kadeřábková A. 2007. Technology Intensity and FDI in the Czech Republic Competitive Advantage. Politická Ekonomie 55 (3), 354-373.

Kinoshita Y., Campos N.F. 2003. Why Does FDI Go Where it Goes? New Evidence from the Transition Economies. William Davidson Instutute Working Paper Number 573.

Kočenda E., Valachy J. 2001. Secondary Privatization in the Czech Republic - Changes in Ownership and Enterprise Performance in Voucher-Privatized Firms. Warsaw, Case - Center for Social and Economic Research.

Krugman P., Obstfeld M. 1997. International Economics. AddisonWesley, New York.

Lankes H.P., Venables A.J. 1997. Foreign Direct Investment in Eastern Europe and the former Soviet Union: Result from a Survey of Investors. In Zecchini S. (ed.): Lessons from the Economic Transition. Central and Eastern Europe in the 1990s. Kluwer Academic Publishers and OECD, Norwell, Massachusetts.

Mody M. 2004. Is FDI Integrating the World Economy?. The World Economy 27 (8), 1195-1222.

Mody M. 2007. Foreign Direct Investment and the World Economy. Routledge.

O'Brien M. 2007. A caution regarding rules of thumb for variance inflation factors. Quantity and Quality 41, 673-690.

Prescott E.C. 1998. Needed: A Theory of Total Factor Productivity. International Economic Review 39 (3), 525-551.

Pomery C. 1997. The First Czechlnvest Annual Survey on FDI in the Czech Republic. Czechlnvest, Praha.

Pye R.B.K. 1998. Foreign Direct Investment in Central Europe: The Experience of Major Western Investors. European Management Journal, Special Issue.

Rousseeuw P.J., Leroy A.M. 1987. Robust Regression and Outlier Detection. New York, J.Wiley.

Savary J. 1997. The French Firms Motivation for Investing in Eastern Europe Countries. A Study of Investors and Potential Investors. In Witkowska J., Wysokinska Z.: Motivations of Foreign Direct Investors and Their Propensity to Export in the Context of European Integration Process. University of Lódz, 43-76.

Smarzynska B., Spartareanu M. 2004. Do Foreign Investors Care about Labor Market Regulations? Policy Research Working Paper Series 3275, The World Bank.

Víšek J.Á. 1996. On High Breakdown Point Estimations. Computational Statistics, Berlin 11, 137-146.

Víšek J.Á. 2000. On the Diversity of Estimates. Computational Statistics and Data Analysis 34, 67-89.

Walsh Y. 2010. Determinants of Foreign Direct Investment: A Sectoral and Institutional Approach. IMF Working Paper. 10 (187).

Wooldridge J.M. 2003. Introductory Econometrics: A Modern Approach. 2nd Edition. Mason, Ohio: South-Western - Thomson Learning.

Zamrazilová E. 2007. Foreign Direct Investment in the Czech Republic: Selected Macroeconomic Issues. Politická ekonomie 55 (5), 579-602. 